\title{
THE DECLINE OF THE FAMILY WORK UNIT IN BLACK COUNTRY NAILING
}

In his study of the effect of technological change on families working in the Lancashire cotton industry in the first half of the nineteenth century, Smelser has argued that the family as a work unit was disrupted by the introduction of larger mules, which required more child assistants in the spinning mill than one family alone could provide. The result was the disruption of the family work unit, hitherto preserved in the earlier cotton mills, and the decline of the old apprenticeship system based on kinship. ${ }^{1}$ It should be instructive, therefore, to attempt a comparative investigation of conditions in the family work unit in Black Country nailing in the second half of the nineteenth century, when the trade faced increasing competition from factorymade nails and died a lingering death similar in some ways to that of handloom weaving. ${ }^{2}$ For the purposes of this article, the family work team of the nailers of Stourbridge and district will be examined in the light of the quantitative evidence of the 1851 census returns, and then the decline and disintegration of the work unit will be discussed, with particular reference to changes in familial roles. Here of course it will be impossible to separate work roles from social roles within the family, since so much time was spent by all members within the nailshop, and the distinctive life-style of nailers was strongly conditioned by their mode of work. Lastly, some suggestions will be made as to the causes

1 Neil J. Smelser, Social Change in the Industrial Revolution (1969), ch. X, especially pp. 196-99.

2 A useful description of the state of the trade in the 1860's is to be found in Ephraim Ball, "The Hand Made Nail Trade", in: Birmingham and the Midland Hardware District, ed. by Samuel Timmins (1866). General accounts of Black Country nailing are available in W. H. B. Court, The Rise of the Midland Industries 1600-1838 (1938), H. C. Allen, The Industrial Development of Birmingham and the Black Country, 1860-1927 (1966 edition), and E. I. Davies, "The Hand-made Nail Trade of Birmingham and District" (unpublished Birmingham M.A. thesis, 1933). Methods of making nails are described in A. F. Moseley, "The Nailmakers", in: West Midland Regional Studies, II (1968). 
of decline, and the general significance of the changes which took place in the family.

In the mid nineteenth century, Stourbridge was a thriving industrial town situated in the South-West corner of the Black Country, twelve miles west of Birmingham and a similar distance south of Wolverhampton. Although well-known for its glass industry, it was very much an iron town, its prosperity being based very largely on finished iron; the largest works were those of Bradley \& Co., owned by James Foster. ${ }^{1}$ Of the importance of the iron industry as a whole in Stourbridge at this time, there can be no doubt; it employed far larger numbers than any other industry - over four times the number of domestic servants, nearly nine times the number of glass workers, and about fourteen times as many as wood workers, or bootmakers, or agricultural labourers. Moreover, more than half the iron workers were nailers $-2,118$ out of a total of 3,547 iron workers of all kinds, many of these living in the strongly nailing villages of Lye and Wollescote. Thus, nailing was the most important single occupation in Stourbridge and district in $1851 .^{2}$

The nailing family in 1851 was not particularly large. Reference to the table will show the average size of families in Lye and Wollescote to be 4.6 and 4.9 , respectively. ${ }^{3}$ Obviously, since these are average figures, there existed families both larger and smaller than this, but generally speaking nailing families contained less than three children in 1851, when all families are taken into account from the family of one person upward. Further, most families were nuclear families, ${ }^{4}$ and the proportion of extended families to nuclear families was actually

1 The size of the works in the principal industries in the area throughout the nineteenth century is examined in my article "Changes in the Scale of the Industrial Unit in Stourbridge and District, 1815-1914", in West Midlands Studies, VIII (1975).

2 For a detailed occupational analysis, see my article "Working Conditions in Victorian Stourbridge", in: International Review of Social History, XIX (1974). 3 These figures may be compared with Peter Laslett's conclusion that the mean household size in England remained fairly constant at 4.75 or a little under from the late sixteenth to the early twentieth centuries. Peter Laslett, Household and Family in Past Time (1972), p. 126.

4 For the purpose of the analysis contained in the table, the terms "nuclear family" and "extended family" have been employed in the simplest possible sense to distinguish between separate family units, those on the one hand containing a man and/or woman with or without children, and, on the other hand, families containing kin other than offspring. This classification is open to the objection that one-person families are not in fact "families", but the number of these in the sample was extremely small, and their inclusion simplified classification. For examples of more refined definitions and categorisation, see Laslett, op. cit., pp. 28-32. 
Analysis of Sample Households in 1851

Dis- No of Av. size Av. size No of No of No of $f^{\prime}-$ No of No of h'trict h'holds h'hold family nuclear ext. lies w. lodgers holdsw.

f'lies f'lies lodgers servants

\section{Stourbridge Town}

$\begin{array}{llllrllll}\text { 1A } & 16 & 4.7 & 4.0 & 12 & 4 & - & - & 3 \\ \text { 1B } & 15 & 4.9 & 3.7 & 11 & 4 & 3 & 5 & 6 \\ \text { 1C } & 11 & 5.0 & 4.4 & 7 & 4 & - & - & 3 \\ \text { 1D } & 11 & 3.6 & 3.1 & 8 & 3 & - & - & 2 \\ \text { 1E } & 17 & 4.7 & 4.4 & 15 & 2 & 2 & 4 & - \\ \text { 1F } & 11 & 4.0 & 3.9 & 7 & 4 & 1 & 1 & - \\ \text { 1G } & 15 & 4.4 & 3.7 & 13 & 2 & 2 & 9 & - \\ \text { 1H } & 13 & 3.4 & 3.3 & 12 & 1 & - & - & 1 \\ \text { 1I } & 14 & 3.8 & 3.1 & 13 & 1 & 2 & 2 & 7 \\ \text { 1J } & 17 & 4.4 & 3.9 & 13 & 4 & 1 & 4 & 3\end{array}$

Lye

$\begin{array}{lrrrrrrrr}2 \mathrm{~A} & 11 & 5.3 & 4.5 & 9 & 2 & - & - & 2 \\ 2 \mathrm{~B} & 14 & 3.8 & 3.8 & 10 & 4 & - & - & - \\ 2 \mathrm{C} & 13 & 4.1 & 3.9 & 13 & - & - & - & 2 \\ 2 \mathrm{D} & 11 & 5.4 & 5.1 & 8 & 3 & 1 & 2 & 1 \\ 2 \mathrm{E} & 14 & 4.8 & 4.4 & 13 & 1 & 3 & 6 & - \\ 2 \mathrm{~F} & 15 & 3.3 & 3.3 & 15 & - & - & - & - \\ 2 \mathrm{~J} & 12 & 6.8 & 6.7 & 9 & 3 & - & - & - \\ 2 \mathrm{~K} & 9 & 5.7 & 5.6 & 9 & - & - & - & 1\end{array}$

Wollaston

$\begin{array}{llllrllll}3 \mathrm{~A} & 17 & 4.9 & 4.7 & 12 & 5 & 1 & 1 & 3 \\ 3 \mathrm{~B} & 10 & 4.4 & 4.3 & 9 & 1 & - & - & 1\end{array}$

Wollescote

$\begin{array}{rrrrrrrrr}4 \mathrm{~A} & 13 & 5.8 & 5.5 & 12 & 1 & 1 & 1 & 2 \\ 4 \mathrm{~B} & 8 & 5.2 & 5.1 & 6 & 2 & 1 & 1 & 1 \\ 4 \mathrm{C} & 9 & 4.0 & 4.0 & 6 & 3 & - & - & -\end{array}$

Upper Swinford

$\begin{array}{lrrrrrrrr}\text { 5A } & 12 & 6.3 & 5.0 & 8 & 4 & - & - & 6 \\ \text { 5B } & 12 & 4.6 & 3.7 & 8 & 4 & 2 & 2 & 3 \\ \text { 5C } & 9 & 3.1 & 3.0 & 8 & 1 & - & - & 2 \\ \text { 5D } & 15 & 4.1 & 3.7 & 13 & 2 & 1 & 1 & 1 \\ \text { 5E } & 13 & 4.4 & 3.7 & 12 & 1 & 3 & 3 & 2\end{array}$

Amblecote

$\begin{array}{lllllllll}6 \mathrm{~A} & 18 & 4.3 & 4.2 & 17 & 1 & - & 2 \\ 6 \mathrm{~B} & 15 & 4.3 & 4.0 & 13 & 2 & 1 & 2 & 2 \\ 6 \mathrm{C} & 11 & 4.8 & 4.3 & 11 & - & 2 & 3 & 3\end{array}$


THE FAMILY WORK UNIT IN BLACK COUNTRY NAILING

$\begin{array}{ccccccccc}\text { Dis- } & \text { No of } & \text { Av. size } & \text { Av. size } & \text { No of } & \text { No of } & \text { No of } f^{\prime}- & \text { No of } & \text { No of h'- } \\ \text { trict } & \text { h'holds } & \text { h'hold } & \text { family } & \begin{array}{c}\text { nuclear } \\ \text { f'lies }\end{array} & \begin{array}{c}\text { ext. } \\ \text { f'lies }\end{array} & \begin{array}{c}\text { lies } w . \\ \text { lodgers }\end{array} & \begin{array}{ll}\text { lodgers } \\ \text { holds w. } \\ \text { servants }\end{array}\end{array}$

Summary

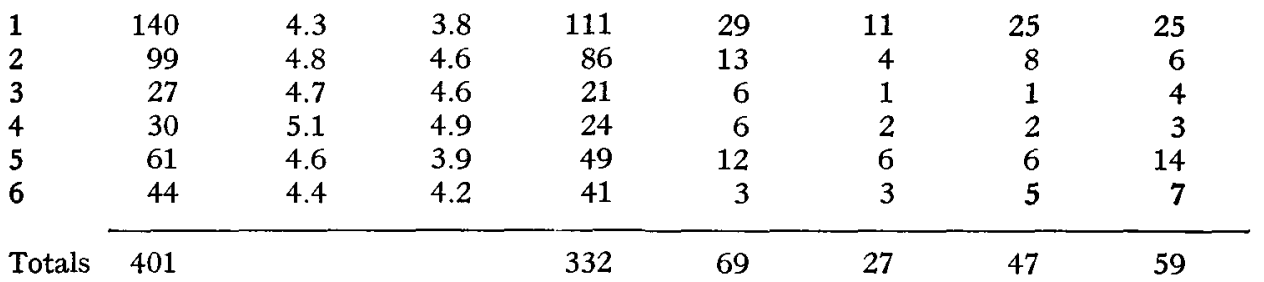

Note: This analysis is based upon a one-in-ten sample of households contained in the 1851 enumerator books. Street samples were also examined - the whole of District 1A, then for nailers Crabbe Street and the Waste, for miners Bott Lane, for finished-iron workers Bowling Green Lane and Spring Lane, and for glass workers Dennis Park.

lower in Lye, an overwhelmingly working-class area, than in Stourbridge itself, which was much more middle-class in character; in Wollescote, similarly a strongly working-class area, the proportion was about the same as in Stourbridge. ${ }^{1}$ It appears from this that the suggestion sometimes made that the nailers' families were very large so as to provide a substantial workforce is unfounded for the Stourbridge area. ${ }^{2}$ In fact, the average number of children per family in all the nailing families within the sample was 2.8 , as compared with 2.7 in the families of finished-iron workers, and 2.5 in the families of miners and glass workers. The differences between these figures do not seem to be very significant, though it may be that the practice among nailers of marrying very young (to which we shall return later) may have had some effect.

As for the differences between average family sizes in Lye and Stourbridge (4.6 compared with 3.8 ), this seems a consequence of the middle-class character of the central town area. The two districts with the greatest number of middle-class residents, Stourbridge and Upper Swinford, have about the same average family size (3.8 and 3.9), while there is a similarity between the three predominantly working-class areas, Lye, Wollescote and Wollaston (4.6, 4.9 and 4.6). Amblecote socially lies between the two groups, and the average family size is appropriately 4.2. This does not mean, however, that middle-class

1 The number of middle-class families in Lye and Wollescote was very small; there was not a single doctor, architect, surveyor or solicitor resident there. A count based on the enumerator books gives a figure of 288 for middle-class families out of a total population of 5,901.

${ }^{2}$ On this point generally, see E. A. Wrigley, Population and History (1969), pp. 161-63. 
families necessarily had fewer children. The better reason appears to be that in Stourbridge and Upper Swinford there was a number of retired residents living on annuities, sometimes with servants. Small families of this kind are conspicuously absent in Lye and Wollescote no-one in his senses would wish to retire to such places, and indeed the local practice was for the successful man of Lye to retire to Stourbridge. If middle-class families were smaller, it was so only marginally, while middle-class households were larger on average, as one might expect, because of the number of servants employed. ${ }^{1}$

It is certainly true that the extended family was in no way characteristic of nailing families in Lye and Wollescote, provided our investigation is confined to individual households. In fact, there were fewer extended families proportionately in Wollescote than in Wollaston, where there were very few nailers - none at all as heads of households in the sample -, and this holds good even when "extended family" is taken to include in-laws, as it is here, and not necessarily grandchildren. ${ }^{2}$ The classic case in which grandparents live in the same house as their married children and their grandchildren must have been very rare in the area as a whole; no single case of this situation was revealed by the sample. When grandparents are to be found, they are usually still working, and sometimes looking after one or two grandchildren. Sometimes they will have a widowed son or a daughter living with them, but rarely. One can only guess at the explanation here. In some cases the parents may be dead or separated, while in others it might be that parents with larger families found it convenient to pass over one or two children to the grandparents for a time to ease the strain on both the mother and living space.

However, if the term "extended family" is no longer employed exclusively with reference to individual households, but is used in a wider sense to include relatives within easy walking distance, then it will appear that the extended family is prominent, after all, in both Lye and Wollescote. Kinship ties were probably very strong in the nailing areas. In no other part of the whole district do surnames reoccur so frequently. Thus, of the twenty-two households in Crabbe Street, Wollescote, four were headed by a Wooldridge (Nos 55, 57, 59, $64)$, three by a Perks $(61,62,77)$, and three by a Pardoe (74-76). Since immigration into the area locally was so limited (a point which will

\footnotetext{
${ }^{1}$ Similar conclusions are reached for York in the years 1841 and 1851 in W. A. Armstrong, "The Social Structure of York, 1841-1851: an essay in quantitative history" (unpublished Birmingham Ph.D. thesis, 1967), ch. V.

2The term "extended family" has been used very loosely in the past, and not always so as to include in-laws. For an interesting attempt at a definition, see G. Duncan Mitchell, A Dictionary of Sociology (1968), pp. 76-78.
} 
be discussed later), it is highly likely that these were cases of children living close at hand, and sometimes literally next door to their parents. Family relationships accordingly must have been important even though grandparents, parents and children were not actually under the same roof. Indeed, one might even ask how much stronger ties would have been had they all been sharing the same accommodation. ${ }^{1}$ Nevertheless, a relative living next door is still free to make individual choises in furnishing, preparing food and cooking it, and so on, so that the maintaining of a separate household may still permit significant variations in the pattern of single-household family life. For this reason it would be unwise to assume too readily that there is little or no difference between the extended family based on one household and the extended family based on two or more households in the same street. $^{2}$

To round off this description of the structure of the nailing family in the mid nineteenth century, some reference is necessary to lodgers and servants. As for the former, it is evident from the table that lodgers were very few in number in Lye and Wollescote. Nor is this surprising in view of the static nature of the community in the first half of the century, so that there was little demand for lodgings for immigrants. ${ }^{3}$ Servants were similarly limited in number in the nailing districts. Generally speaking, even the skilled workman did not keep a domestic servant while his wife was still living, and in Lye and Wollescote there were only two cases in the sample of a workman employing a servant. The situation was different, of course, when there was no wife or mother in the family, and this appears to be the most common reason for a working man to have a servant, that is, to serve as a housekeeper for himself and the children.

To turn now to the family at work: it is impossible to say precisely what division of labour was adopted within the family, but there is no doubt that the women and children had to work very hard. In particular, the wife and mother had to attend to household duties and to the children when she was not working in the nailshop. On Mondays the washing and cleaning had to be done while the man of the house

1 The view has been expressed that there was no difference in this connection between a co-residing kinsman and one living next door or up the street. Michael Anderson, Family Structure in Nineteenth Century Lancashire (1971), pp. 56-57. ${ }^{2}$ It is perhaps appropirate to mention the classic study of related working-class families living in the same street in the mid twentieth century: M. Young and P. Willmott, Family and Kinship in East London (1957).

3 The comparison with Preston in 1851 is very marked, where lodgers were present in 23 per cent of the households, and constituted "a sociologically significant element in the population". Anderson, op. cit., pp. 46-47. 
took a rest. ${ }^{1}$ It was often alleged that when the father was aged thirty or more he would give up work, and live on the labours of his wife and children. ${ }^{2}$ Mealtimes might be irregular, and nailing families were notorious for their poor diet and wretched home conditions. ${ }^{3}$ It could scarcely be otherwise when the mother spent so much time at the bench, leaving babies to be looked after by small girls. When the children grew up, they would marry and form a new family work unit which perpetuated the traditional work situation. The children in the worst condition in the area in 1842, it was said, were invariably those working at home. ${ }^{4}$ The family work unit at the mid century was thus a mode of work organisation which was associated with the worst living and working conditions in the district.

When individual roles within the nailing family are examined, it is apparent at the outset that the role of the father was indeed commanding. He alone in the family controlled the total work situation. As the strongest adult he could (if he chose) work longer than anyone else, and in the nailing family he might be the only adult strong enough to operate the oliver (the spring-loaded hammer worked by a treadle) by himself. ${ }^{5}$ In this position of authority he would decide the hours for the working week and, subject to the work available, thereby determine the weekly income. If he wished, he could idle his time away and get drunk, knowing that his wife and children would finish the work if they wanted to eat at the end of the week when the nails were taken to the warehouse. Drunkenness was common in the area as a whole, but the heavy drinking among the nailers in Lye was notorious. ${ }^{6}$

Unlike the wife of a man working outside the home, the wife of a nailer would be expected to share her husband's work, and in the Lye and Wollescote enumerator books she is almost invariably given the occupation of nailer. As noted earlier, she was mother, housekeeper

1 For St Monday in the Stourbridge area, see my "Working Conditions in Victorian Stourbridge"; for the wider context, see E. P. Thompson, "Time, Work-Discipline, and Industrial Capitalism", in: Past \& Present, No 38 (1967). ${ }^{2}$ Children's Employment Commission, Appendix to Second Report [Parliamentary Papers, 1843, XV], pp. 80-81, evidence of Mr Betts, surgeon to the Stourbridge union; Reports of Inspectors of Factories, April 1875, report of $\mathrm{Mr}$ Brewer.

s Children's Employment Commission, ibid.

4 Ibid.

5 This refers to the larger oliver used to cut cold the largest nails or spikes, which could only be operated by a woman if a man or boy jumped on the treadle behind her. Smaller olivers could be used by a woman alone.

- According to D. Robertson, Recollections of Lye Parish, 1866-1875 (1914), there were 53 public houses for a population of about 7,000. In addition, there were numerous beer shops and wobble shops, i.e. unlicensed premises which sold beer. 
and industrial worker all in one, and her subordinate position in the family economy was emphasised by her being sent to deliver nails on Saturdays and to collect nail rod on Mondays. When the Workshops Act, 1867, forbade the employment of children under eight, and limited the hours of children between eight and thirteen to six and a half, even greater burdens were placed on the nailer's wife. Of course, it took some time for the act to be enforced, but its restrictions were reinforced by the provisions of the Education Acts of 1870, 1876 and 1880 , and by the regulations against employment under the age of thirteen of the local school boards. Thus, children were gradually withdrawn from the family workshop, leaving the work to be done by the man and wife. In theory, the wife had some protection herself under the 1867 Act, since this limited the hours of women and young persons to ten and a half daily; but in practice nailshops where only the man and his wife were working were not subject to inspection, presumably because the wife was not recognised as an employee. Certainly it was not usual to proceed against a man for overworking his wife, and where a woman hired a stall or bench herself in a workshop, she virtually became an occupier, and could not be prosecuted for overworking herself. ${ }^{1}$

Thus, workshop legislation failed to ease the burdens of the nailing mother. On the contrary, it probably intensified them as the children went off to school, and the parents were left struggling to earn a living in the increasingly difficult conditions of the hand-made trade. For such women in Lye and Wollescote, the eventual extinction of the trade and alternative employment in the local hollow-ware factories, where restrictions on hours were enforced, must have come as something of a liberation. Far from bringing industrial servitude to these women, the factory system helped to emancipate them from an outmoded system of domestic industry which had degraded and exploited them. ${ }^{2}$

As for the children, they were born into the work situation, and they had little prospect of employment in any other trade. Traditionally nailers married young, the girls even as young as fifteen, and by the time they were really women they would have a family of young children. ${ }^{3}$ The early marriage registers do not give exact ages, but of

1 Evidence of Inspector Hoare in the Third Report of the Select Committee of the House of Lords on the Sweating System [PP, 1889, XIII].

${ }^{2}$ For a general survey of the position of women in the nailing trade in the Black Country in the 1890's, see the report by Eliza Orme on the condition of women in the nail, chain and bolt making industries of the Black Country, in Royal Commission on Labour, Minutes of Evidence, Group A, Vol. II [PP, 1892, XXXVI], pp. 571-75.

${ }^{3}$ See the evidence of Mr Betts, the surgeon, noted above. 
the 24 Lye and Wollescote brides married at St Mary's in 1841 who were described as nailers, 15 were of full age and 9 under age. ${ }^{1}$ Of these 24 brides, 15 married either nailers or chainmakers. Even as late as 1892 it was said that boys and girls of seventeen or so would marry in the nailing trade, and each would continue to live and work in the parents' home. ${ }^{2}$ Nailing girls would commonly mind the baby as soon as they were old enough to do so, then work in the family workshop until they were married.

In short, in the middle decades of the nineteenth century, these nailing families present a classic instance of the patriarchial, multifunctional family, in which the father has a strongly dominant role, with the wife and children fulfilling correspondingly subservient roles. In such circumstances it is obvious that family life must have been the principal agent for socialisation and, if relatives lived as closely together as indicated earlier, then contacts with the external world must have been limited in nature. There is no doubt that the people of Lye lived a life of relative isolation at this time, and that they were an inbred, slow-moving community. In 1851, 82 per cent of the inhabitants of Lye had been born there, and 88 per cent of the inhabitants of Wollescote (the corresponding figure in Stourbridge town was 55 per cent, Upper Swinford 49 per cent). ${ }^{3}$ In the 1860's the Worcestershire Chronicle refers from time to time to Lye Wasters (those living on Lye Waste) or Lye Savages, while Lord Lyttelton called them "these peculiar people"." Noake wrote of their individual way of life, their nicknames and their famous mud cottages ${ }^{5}$ (the cottages were of thatched clay rather than mud, but Lye was still known locally as the Mud City), and so did Robertson. ${ }^{6}$ The one real disturbance in the entire district during the Chartist troubles took place on Lye Waste in 1839 , when a squadron of yeomanry en route for Birmingham was assailed by a mob who hurled stones and set bulldogs on the horses. ${ }^{7}$ In 1874 the General Election led to rioting in Lye and attacks on the police

\footnotetext{
${ }^{1}$ Marriage register of St Mary's, Old Swinford, for 1841 . There were 16 brides under age in all from Lye and Wollescote, of whom 9 were nailers, while of the remaining 7 the occupations of 5 were not given. It is quite likely that some of these 5 were nailers.

${ }^{2}$ Report by Eliza Orme, loc. cit., p. 573.

${ }^{3}$ Figures based on a one-in-ten sample of places of birth in the 1851 enumerator books. In Preston, 53 per cent of the population had been born outside the town's boundaries, Anderson, op. cit., p. 203.

4 See for example Worcestershire Chronicle, 1 February 1860 and 3 April 1861.

5 J. Noake, The Rambler (1854), pp. 253-56.

- Robertson, op. cit.

7 Home Office Papers 40/48, Disturbances.
} 
- described by a local newspaper as "displays of aimless and idiotic violence". 1

It would be foolish, of course, to ascribe all this to the continued existence of the family work unit, and it may be that the very marked exclusiveness of the Lye and Wollescote communities was atypical of Black Country nailers as a whole. Nevertheless, the organisation of industry on a domestic basis must have contributed powerfully to the maintenance of traditional attitudes and practices which were already breaking down in the adjacent communities. In these areas where the father worked away from home, the modern industrial family had already evolved - that is to say, a family in which both the father and children worked outside the home to set hours, establishing relationships at work beyond the narrow range of the extended-family circle. Moreover, neighbours in Stourbridge, Upper Swinford, Wollaston and Amblecote were very much more likely to have come from outside the area because of the greater proportion of immigrants in these districts. The function of the wife and mother in these more modern families also seems to be different; few appear to have been working outside the home in full employment. Occupations are rarely given in the 1851 enumerator books for the wives of men working outside the home. Occasionally the wife may be described as a charwoman or laundress, but in the vast majority of cases she is given no other occupation than that of housewife. ${ }^{2}$ It seems therefore that the role of the wife in this kind of family was limited to housekeeping and child-rearing. ${ }^{3}$ Thus,

1 Stourbridge Observer, 14 January 1874. Commotions were common enough in Lye, where a general free-for-all was known as a Cole's Wake. No doubt family feeling on occasion added an edge to disputes of this kind.

${ }^{2}$ Allowances must always be made for possible errors and omissions by individual enumerators, but there seem to be no significant differences in this respect between the wives of miners, finished-iron workers, brickmakers and glassmakers. On the subject of mistakes in entering women's occupations in enumerator books, see P. M. Tillott, "Sources of inaccuracy in the 1851 and 1861 censuses", in: Nineteenth Century Society: Essays in the use of quantitative methods for the study of social data, ed. by E. A. Wrigley (1972), pp. 121-22.

${ }^{3}$ By way of comparison, most women workers in the new cotton mills also seemed to have stayed in the home after marriage. See Ivy Pinchbeck, Women Workers and the Industrial Revolution, 1750-1850 (1930), pp. 197-99; Margaret Hewitt, Wives and Mothers in Victorian England (1598), p. 290; Anderson, op. cit., p. 71, who suggests, that in Preston 26 per cent of wives living with their husbands worked, but that probably only 15 per cent of wives with children worked away from home for most of the day. Per contra, it has been estimated that in Oldham and Northampton over one-third of mothers with children aged eleven or under went out to work, John Foster, Class Struggle and the Industrial Revolution (1974), pp. 96-97. See also Eric Richards, "Women in the British Economy since about 1700: An Interpretation", in: History, LIX (1974), pp. $345-48$. 
two kinds of family existed in the Stourbridge area at this time: the pre-industrial-revolution family in Lye and Wollescote, already becoming an anachronism by the mid century, and the more modern family characteristic of the new industrialised economy, working away from home and subject to newer work disciplines, but with a wider range of social relationships. ${ }^{1}$

Although it is often said that the nailing trade began to suffer from the competition of machine-made nails from 1830 onwards, it was not until the 1860 's that machinery was improved sufficiently to have a really serious effect on the trade, and cheap foreign nails were being imported from Belgium and Germany by the 1880's. Even then, the trade was said to be flourishing locally in the boom period of the 1870 's, ${ }^{2}$ but there can be no doubt that thereafter the road was steadily downhill. The precise mode of disintegration of the family work unit naturally varied from family to family. In some cases, efforts were made to continue domestic work by changing to chainmaking ${ }^{3}$ or the making of frost cogs (studs fitted to horseshoes in frosty weather to give a better grip). In others, the majority of cases, the male workers deserted nailing altogether and entered other trades such as mining or hollowware manufacture, leaving the women to continue making nails at home. ${ }^{4}$ In still other instances, so-called nail factories were set up in which no machinery was used, but which consisted of several nailing shops on the same premises with eighteen to thirty workers. These were often large sweatshops run by foggers (middlemen who bought nails at low rates, afterwards selling to the established nailmasters)..$^{\mathbf{5}}$ By the turn of the century these workshops had been replaced very largely by factories in which nails were made by machinery. ${ }^{\circ}$ The final stage would be reached when the family gave up nailing for good, and all members of the family of working age might be employed ouside the home. Many families must have reached the penultimate stage by the 1890's, and by 1914 nailing had been deserted locally by the younger generation. In 1911 and again in 1913 not one groom married in the Anglican churches of the area was a nailer. In 1912 there was one such

1 There was probably little difference in the aggregate between the hours worked at home and away from home, though the domestic worker could choose his own hours so as to include both St Monday and working all night on Friday.

2 Reports of Inspectors of Factories, April and October 1875.

3 Evidence of Inspector Hoare, loc. cit., p. 457.

4 Evidence of Thomas Cole of Lye Waste, ibid., p. 352.

5 Report by Eliza Orme, loc. cit., pp. 573-74, and evidence of William Price, ibid., pp. 454-62.

- The Black Country and Its Industries, published by the County Express (1903), see accounts of the firms of J. Skelding and B. Baker. 
groom, but significantly he was aged 70 and married a widow of 67 ; they were the only couple married that year who were unable to sign their names. ${ }^{1}$

By this time radical changes had taken place within the family in Lye and Wollescote. The decline of nailing meant that children who in former years would have become nailers now attended school before going into another trade, some of them into one of the newer occupations now available, such as working on the railway or on the trams, where they worked set hours. Further, marriage patterns were now changing. Of the 134 brides married at Christchurch, Lye, in the years 1911, 1912 and 1913, not a single one married a nailer, and only 23 were under age, that is, about a sixth compared with a third in $1841 .^{2}$ Perhaps the greatest change of all was the loss of what might be termed patria potestas by the nailing father, whose authority over wife and children was now greatly diminished. By 1914 the differences in essential structure and relationships between families in Lye and Wollescote and families in the rest of the Stourbridge area must have been very slight. Both types of family had to resemble much more closely the twentieth-century kind of family, no longer multifunctional, in which parental authority is shared with schoolteachers, inspectors and the various forms of welfare agencies.

The causes of this decline of the family work unit in the Black Country nailing trade seem at first sight to be obvious enough, namely, the technological changes in the manufacture of nails. But this is to ignore the labour difficulties resulting from the reduction of hours and the education clauses in the Workshops Act, 1867, and from the Education Acts of 1870,1876 and 1880 . It may be that the restriction first of children's hours of work, then the coming of compulsory education constituted as powerful a solvent of the domestic work unit and of the old-style family as cheap machine-made nails. Add to this the local trade depression of the 1880's and the growth of alternative prospects in the new hollow-ware industry in Lye, and it is apparent that domestic industry in the area was eroded by a number of different forces. Hence it is suggested that whatever the importance of the various contributory causes, it would be wrong to see the decline of the family work unit in nailing as simply the result of technological change

1 Based on an analysis of the registers of St Mary's, Old Swinford; St James's, Wollaston; Christchurch, Lye; St Thomas's, Stourbridge; St Mark's, Stambermill; St John's, Stourbridge; and Holy Trinity, Amblecote. The evidence for the desertion of nailing by the young is confirmed by the Baptismal Register of Lye Waste Primitive Methodist Church, which does not contain a single nailer for the period 1900-14.

2 See marriage registers of Christchurch, Lye, for the years concerned. 
within the area itself. Rather it was the national change to industrialisation coupled with the population explosion which together produced social stresses of such a kind that the government was obliged to take action in the fields of working hours, education and public health. This action took effect in the Stourbridge area on a trade already suffering from competition with a machine-made product. Thus, the differentiation of new labour roles in the family economy - to use Smelser's phraseology - came not directly as a result of the coming of the factory system, but by a more complicated operation of technological change and government social legislation.

It remains to evaluate the changes which came about in the family work system. In the first place, enough has been said to provide ample confirmation for the Stourbridge area of Laslett's views as to the non-existence of the extended family as a unit in England before the Industrial Revolution. The extended family was certainly comparatively rare in the main nailing areas in 1851: 13 per cent of the families sampled in Lye, 20 per cent in Wollescote, and 17 per cent for the Stourbridge area as a whole. ${ }^{1}$ The one qualification here - and it is an important one - is that this point may lose some of its force if the extended family is taken to include relatives living not in the same household, but close at hand. Only a lengthy exercise in nominal linkage might put the matter beyond doubt, but it seems very likely indeed that in such static communities as Lye and Wollescote there was a great deal of in-breeding, and that close kinship ties existed in the nailing streets in the middle years of the century. Even then, whether mere propinquity produced the relationships supposedly associated with the extended family is open to question. In any case, this situation began to change from the 1870's onward as nailing died out, new industries developed, and immigration quickened in pace, especially into Wollescote. ${ }^{2}$

In the second place, although present-day attitudes to the family as an institution are not invariably favourable, yet the break-up of the family in the cotton mills of the early nineteenth century is generally regarded as an unfortunate consequence of technological advance. In the case of the break-up of the family work unit in nailing later on in

1 So many local factors may operate to determine the extent to which relatives may form part of a household - for instance, a shortage of accommodation, or the need for an older person to look after children - that comparisons of one town with another in this respect may not be very meaningful. However, Anderson, in Laslett, op. cit., p. 220, gives the following percentages of households with kin in 1851: York 22; Preston 23; Rural Lancashire parishes 27. Foster, op. cit., p. 99, gives Northampton 14; Oldham 21; South Shields 16.

${ }^{2}$ The population in Wollescote rose by 64 per cent from 1,972 in 1871 to 3,060 in 1881 , with a further rise to 3,458 in 1891 . 
the century, the verdict must be otherwise. Ephraim Ball, himself a nailmaster, described the nailing trade in the Black Country as a disgrace to England. ${ }^{1}$ It is difficult to quarrel with this description. All the nailer gained from his traditional mode of work was the freedom to decide his own working hours, though in total these were bound to be lengthy, particularly as the competition from factorymade nails increased. Hence the extinction of the trade and the disintegration of the family work unit could only have been of benefit to those employed by it, especially the women and children. For the women, as we have seen, employment in the hollow-ware factory meant regular working hours, and from 1897 they were admitted to membership of the iron-plate workers' union. ${ }^{2}$ By 1912, two-thirds of them were unionised, and in the same year they struck successfully for a major increase in pay $^{3}$ - something that would have been unthinkable for women nailers. As for the children, their status was greatly enhanced, while the authority of the parents was correspondingly modified in the last quarter of the nineteenth century. Thus, although the roles of father and mother remained basically the same, the improved status of children brought about a refining of parental roles, and an inevitable loosening of familial ties. The decline of the family work unit played no small part in this process of emancipation.

1 Ball, "The Hand Made Nail Trade", loc. cit.

"Management Committee Minutes of the Lye Branch of Iron Plate Workers Union, 1 January 1897.

${ }^{3}$ Stourbridge Advertiser, 2 March, 13 July, 3 August, 12 October and 23 November 1912 . 